\title{
The Types of Communication Used in Workplace
}

\author{
Sri Hapsari Wijayanti \\ Faculty of Economics and Business \\ Atma Jaya Catholic University of Indonesia \\ Jakarta, Indonesia \\ sri.hapsari@atmajaya.ac.id
}

\begin{abstract}
The academic ability (hard skills) in today's global era is not enough to prepare graduates to enter the workplace. This ability needs to be balanced with the mastery of soft skills that can help to achieve success in social life. One of the important components of soft skills mastered in the workplace is communication. This research aims to identify the types of oral and written communications along with the language used in the business by accounting scholars. This study used descriptive qualitative and quantitative methods. Respondents in this study were graduates of accounting from several universities in Jakarta, thirteen people, male and female, had worked for at least two years, and native speakers of the bahasa Indonesia. Data collection technique is done by spreading the questionnaires by asking respondents to choose the types of communication done in their workplace in accordance with their professions. Besides the questionnaires, this study used semi-structured interviews. The interview results are then verbatim transcribed. Interview transcripts will be interpreted to mean the purpose of the study. The results of the questionnaire will be described by calculating the frequency and percentage. The results of this study indicate that in oral communication respondents interact more over the telephone (85\%) and discuss with colleagues or leaders $(53.8 \%)$. In writing communication respondents use email $(77 \%)$ and memo $(46,2 \%)$. The language used in calling, discussing and writing memos is bahasa Indonesia, while both English and bahasa Indonesia are used to writing emails. This study concluded that oral and written communications are equally important to be mastered by accounting graduates in the work life. English becomes important used in written communication to send and reply to emails.
\end{abstract}

Keywords—communication, accountant, hard skill, soft skill, bahasa Indonesia

\section{INTRODUCTION}

The academic ability (hard skill) in global era is not enough to prepare graduates of higher education for the job market. This capability needs to be matched by the mastery of soft skills that are believed to be more important for career success [1]. Communication is "a two-way process of exchanging ideas or information between human beings" [2]. The ability to communicate is important not only for the employers but also for the companies. For employers, the ability to communicate effectively can improve their career, credibility, and professionalism. Companies will also get the benefit, such as enhancing the company's reputation; increase productivity and hasten problem solving; clarify and make messages more persuasive [3].

Communication in the business context is different from in daily life. Business communications have a special purpose of informing a product or an idea; collaborating; influencing others people to take action [4]. The communication skills required in the business include effective writing and speaking [5]. However, Christensen [6] finds that English language skills are further importantly than writing and speaking skills.

Many professions have demand the ability of employers in communication skills. The general need of job market for communication is revealed from the Francis W.
Weeks survey, as cited in [7]. According to him, from 340 employers in 30 occupations, it is known that communication skills are necessity. These needs include the ability to communicate effectively with management levels, presentations, analyzes, writing reports and proposals, correspondences, selling ideas, working groups, and interpreting data. The ability to communicate is also important for accounting graduates, who work as auditors, analysts, consultants, researchers, or educators. Accounting graduates need communication skills before entering job market [8].

From research conducted in accounting firms at three professional levels (entry, middle, and partner), oral presentation, writing, interpersonal relationships, listening and interviews are important types of communication for accountants [9]. This result is supported by AECC (1990), as cited in Stowers \& White [10], who found that communication, intellectual, and interpersonal skills are the keys to accountant success in the workplace. They also revealed that entry level employers require more mature preparation to communicate effectively than the levels above. Those who work at entry level should have writing skills [11].

Studies of needs analysis about the accounting graduates of communication skills described above have been discussed over fifty years ago [12]. However, previous research reports still use a narrow scope and 
limited geographical locations, such as Australia, New Zealand, UK, Singapore, and the US. In Asian countries, China for example, compared to the USA, the need for communication skills by educators and accounting professionals is lower [13].

In addition to research on the analysis of the needs of the accounting graduates, other studies focus on the learning curriculum of communication practices in education to prepare careers as accountants graduates [14]. It is recommended that synergy between teachers, practitioners, and communication especially in designing an accounting education program is recommended [15]. University must redesign the curriculum more real life like the job market [16]. Business communication education at AACSC International Business College, for example, has been shown to have a long-term and shortterm positive impacts in developing report writing skills, problem solving, teamwork, oral communication, and internet use [17].

From previous studies, it appears that the type of oral and written communications have not been reveal the needs of the working for accounting graduates. Therefore, to complement previous research, using a context in Indonesia, this study identifies the types of communication (medium oral and written) and the language used in the workplace for accounting graduates.

\section{METHOD}

This study is a qualitative and quantitative descriptive research. It is said to be qualitative because this study focuses on describing, understanding, and classifying human experience [18]. It is said to be quantitative because this study calculates the frequency of respondents' answers in percentages. Respondents of this study were selected by purposive sampling. The criteria for selecting respondents are graduates of the S-1 faculty of economics-accounting from several universities in Jakarta, totaling 13 people, men and women, working in Jakarta, at least two years work experiences, and native speakers of bahasa Indonesia.

The instrument of this study is a closed questionnaires which divided into three sections. The first section contains demographic of respondents. The second and third sections respectively contain eight types of oral and written communications with four choices: at all times, often, occasionally, and never. Respondents were asked to checklist the type of communications they perform in the workplace in accordance with their professions. In addition, data collections were done by semi-structured interviews. Opinions and experiences of respondents about his professions explored in this interviews. The results of the questionnaires then processed by calculating the frequency of the number and percentage of oral and written communication types. The results of the interview will also be transcribed verbatim and used to find out in detail the types of oral and written communications that are usually done in their company.

\section{DisCUSSION AND RESUlTS}

This study used 13 respondents: 6 male and 7 female, age 24-41 years old, and has worked for 2.5-17 years in national and foreign companies. Although graduates of the S-1 accounting, respondents' occupations vary: accounting staff, marketing staff, supervisors, auditors, analysts, assistant managers, and managers. Due to this varied work, their job description is not the same.

\section{A. Types of Communication in the Workplace}

In general, respondents' occupations related to other people, either people within the company in the same or different divisions or with other parties outside the business-related company. In this study, respondents stated that they communicate within the company's internal and external scope at all levels.

Perform daily report, in the form of a number of perbroker stock transactions. Then calculate the performance of trading results. Then, give input to fund manager for stock purchase. Then, give instructions to the dealer in trading and calculate the performance. (EJ, male).

Several types of communication are conducted by the respondents of this study. In oral communication, respondents often communicate by phone $(85 \%)$ and discuss (53.8\%) (see Figure 1 and Figure 2).

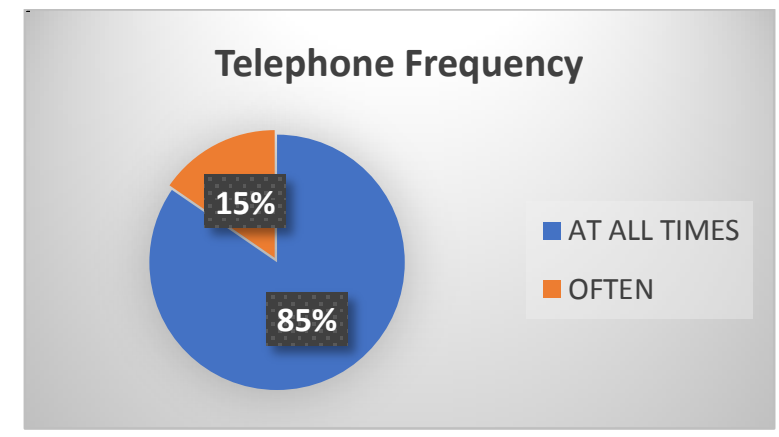

Figure 1. Communication frequency through telephone

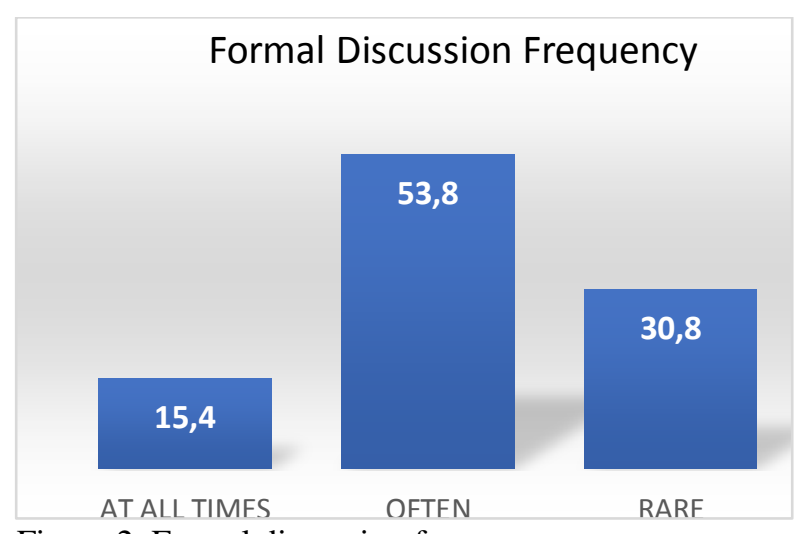

Figure 2. Formal discussion frequency

Telephone communication has done by respondents to connected with colleagues from other branches as done by the following finance operational manager area. 
For oral communication type, by phone, by email. Once the network is damaged because the virus is dead style, fortunately by using the corporate handphone, that all branches have so I decided to use this phone. If this hand phone is out of date it is also "dead style" (laughing) (E, women)."

Besides that, negotiations with clients are also done by phone to saving time as a marketing staff stated below.

Direct face-to-face negotiations are almost never happened. Maybe if there is a lot of trading customers so if we meet need it takes more time. More direction negotiation via email. ( $\mathrm{N}$, female).

Discussion is a communication done jointly with internal and external parties, i.e. boss, clients, or colleagues as stated by respondents who work this auditor.

It must be us if the communication to one auditee because the auditee it let us get client $\mathrm{A}$, client $\mathrm{A}$ will be held the same team that consists of a partner manager in charge same team other members right? After that, for example, we are as Client A there may be issues again, suppose we have an issue that we do not even know until the manager said yes you've tried to ask others, wewill communicate the intention of discussion as the same internal audit team or we have peers yes, as our peers or we ask to our more experienced senior (MI, women).

Telephone communication and discussion are more often done by respondents than presentations (direct or video conference) and negotiations. Presentation in this study was reported by respondents who were at the manager level. These findings confirm Stowers \& White [19] which explains the presentation mostly done at the manager level.

Presentation of material from a branch but selfdirected, presentation in front of a supervisor, team, a branch, material from branch and then recapitulated and presented ( $\mathrm{R}$, female).

This study supports Gray's [20] which states that participating in discussions and communication by phone respectively are important skill in oral communication with clients and colleagues. This study found that the type of written communications that many respondents do is email writing (77\%) and memos writing (46.2\%).

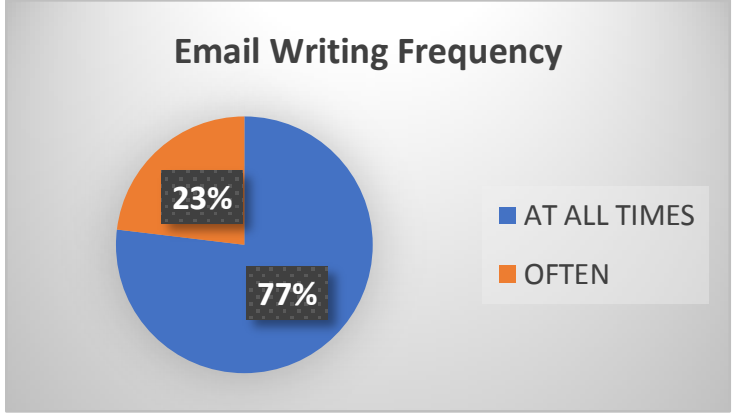

Figure 3. Communication frequency via email

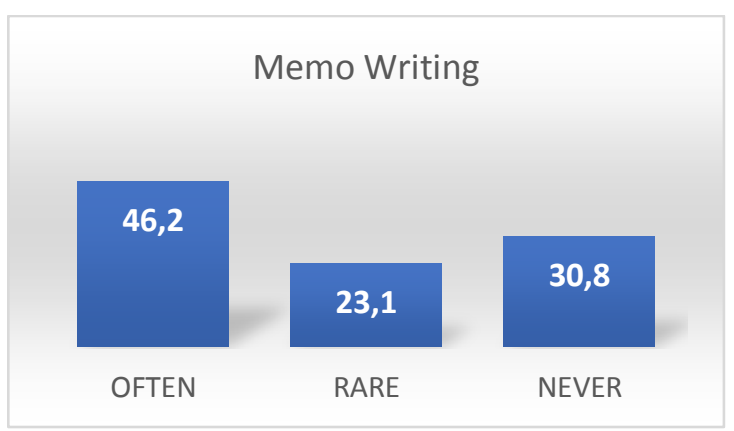

Figure 4. Communication frequency using memo

The following respondent is an entrepreneur operational manager who acknowledge most frequently using emails to correspond with clients in other countries.

Because we operate in our 28 headquarters countries in New York, of course, the most frequent communication we use is email, then conference... (BS, man)

Email is also used for the company's internal communications.

By phone we told them (to trading manager from Korea-writer) or give online ppt by email to be learned beforehand (E, female)

Respondents said that email (especially if there is an attachment) sometimes needs to be corrected by superiors if it will be sent to the external company.

... we see whom we send the e-mail to, for example in my earlier work experience, I have to send an e-mail to the CFO in director level, Then, my e-mail should be reviewed with the people with a higher position than me, so the potential error is definitely reduced (BS, man)

When the respondent communicated via email, the respondent sent it first to the top manajement above him for approval. This indicated the control from the superior to read the contents of the email and then correct the contents is required. In this way, there is no error in delivering messages from the sender because no matter what, what is sent to the external side of the company is dealing with company's prestige. This shows that written communication is most critical for accountants because in 
written communication it needs the ability to organize sentences and paragraphs effectively, write documents clearly and briefly, using proper spelling and grammar, in addition to using email effectively Jones (2011) as cited in [21].

Unlike emails used to communicate with internal and external parties, memos are used for internal corporate purposes, such as requesting a signature or requesting a correction.

Memo if there is a message usually or for example we are looking for someone but he/she is absent so we leave a memo consist of the thing we demanded. And also, if there is a meeting we usually give memo for the person anyway. (internal) (E, female)

\section{B. Language used in workplace}

Whatever the type of communication use, the language used as a means of communication is very important. The message recipient will understand the message which delivered in the language that is understandable for the two. From the interviewer, it was found that English is important in many contexts [22].

In any field of work on a global scale, bilingual ability, especially English proficiency as an international communication language, are a demand [23]. The following respondents say that it is already a consequence of working in the industry with English as intermediate language.

The assumption is that when you get into this industry, you have already to master English (EJ, man).

In this study found that English and Indonesian are both used in their work. In communicating over the phone, discussing, and writing memos were $69.2 \%$ each the respondents used the Indonesian language, while in writing and responding to email $(61.5 \%)$ using bilingual (English and bahasa Indonesia).

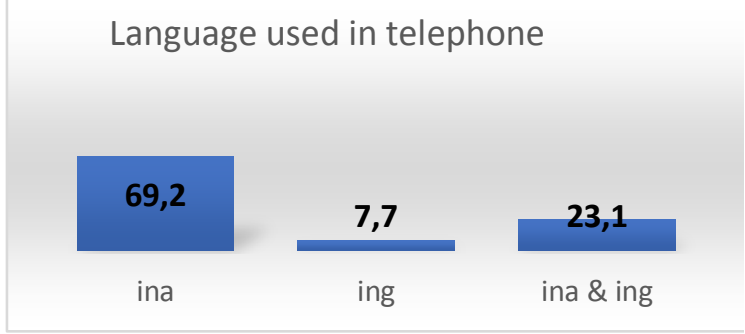

Figure 5. Communication language via telephone

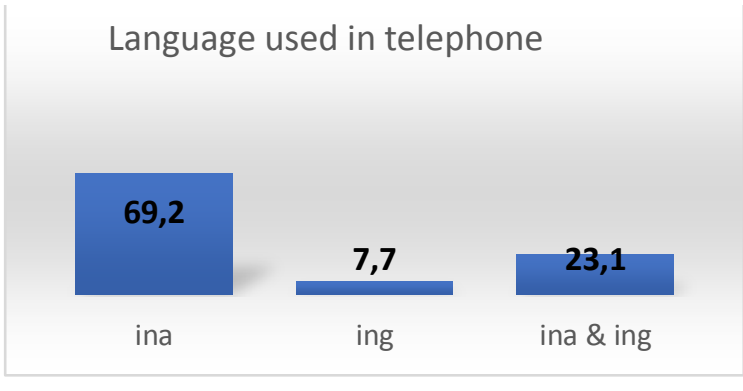

Figure 6. Communication language in discussion

Language used in memo writing

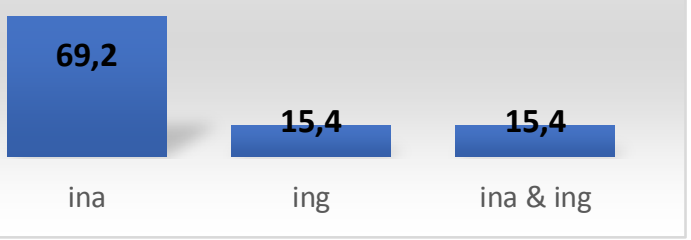

Figure 7. Language in memo writing

\section{Language in email writing}

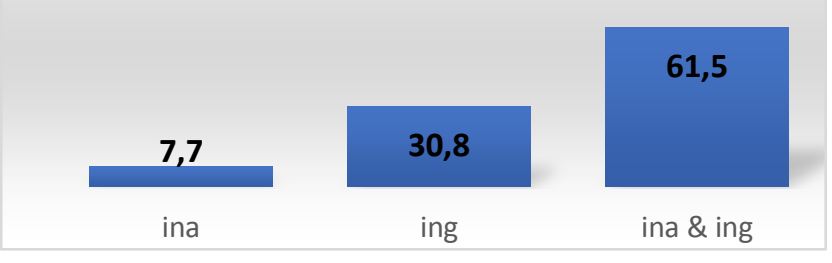

Figure 8. Language in email writing

This study found that talking by phone, discussing, writing memos and emails are job they regularly were done. These findings confirm Sothan [24] argument which stated that memos and emails were the type of written communication that is often done in the business. The difference is that the language used in this study is generally bahasa Indonesia, except writing an email is sometimes also delivered in English to external parties or to their foreign leaders .

However, respondents are still not confident with their ability to speak English. One of the respondents said using Google translate or sederet.com to get the right English word.

Researcher: So, along the time you make email using whether Indonesian or English language, is there a problem such as not make email like email format or email format to the client, but the English must use a very standard English form. Do you find that kind of difficulties or other troubles along the time you make a letter by email? 
Respondent: Not really because I use Google translate.

Although still requires a translator engine, writing an email in English are considered easier for respondents than having to speak English.

E-mail is easier because we can use tools like Google translate sometimes we just need to decide the vocabulary only so it is much better writing e-mail, because we have time to think and decide what is needed, unlike the conference call, it is more difficult because we have to get the point at that moment (AF, female)

Besides email, within making financial statements, respondents must write in two English and Indonesian languages according to the client's request.

Here, is hard by means the results of our work or in the form of financial statements, if in the form of financial statement that there are 2 languages mean depending on the client whether he asked in full English or in Indonesian or can be 2 languages, English and Indonesian language so some in left and the other on the right. However, our working paper or the work we documented must be in English (MI, female)

Often emails or presentations, before they are sent to external parties must be read first by their superiors either to check the language used or review the contents. The goal is to reduce errors.

For the internal communication team, it is important to make it understandable for both parties so it is not a big concern if there is typo or misspelling from the communication side, unless it is a presentation, if the presentation should be reviewed by the superior... (BC, male)

\section{CONCLUSION \& RECOMMENDATION}

The research concludes that accounting graduates can work at any level within an international or national company. The higher level of profession in the company, the greater demand for the ability to communicate spoken nd written language skills. In the workpace, the graduates of accounting will related well with internal and external companies. Therefore, not only interpersonal skills, the ability to communicate verbally and write effectively in bahasa Indonesia and English is an important skill as well. The type of oral communication that is widely used by accounting graduates is to communicate by telephone and discussion.

On the other hand, in written communication, writing email and memo are regularly done. Such work are done because their profession is generally still lower than a manager with an average working time of seven years. In communicating by phone, discussing, and writing memos mostly used in bahasa Indonesia, whereas in written communication to send and reply to email both bahasa Indonesia and English used. The frequency of doing other communications, such as presentation, teleconference, reports-writing, and letters-writing never done by respondents, but it is just not as often as memos and emails, phone calls, and discussions.

This research has a minimum number of respondents; Therefore, the following research is expected to increase the number of respondents. In addition, this research method is interviews and questionnaires. It is expected that in the following research, FGD can be the additional method to be used and questionnaire instruments are designed in more detail and deeper. Apart from that, it is also considered to identify the types of communication in accordance with the professions of the graduates. The results of this research are expected to be an input for learning Business Communication with more emphasis on the practice of oral and written ccommunications that are used in the real work life.

\section{REFERENCES}

[1] Robles, M.M. Executive perceptions of the top 10 soft skill needed in today's workplace, Business Communication Quartely, 75,4 , pp. $453-465$.

[2] Murphy, Herta A. \& Herbert W. Hildebrandt, Effective Business Communication. NY: McGraw Hill, 1991,

[3] Bovee, Courtland L. \& Thill, John V, Business Communication Today, England: Pearson, 2016.

[4] Bovee, Courtland L. \& Thill, John V, Business Communication Today, England: Pearson, 2016.

[5] Murphy, Herta A. \& Herbert W. Hildebrandt, Effective Business Communication. NY: McGraw Hill, 1991,.

[6] Christensen, David S. \& David Rees. "An Analysis of The Business Communication Skill Needed by Entri-level Accountants". Mountains Plains Journal of Business and Economics, 2002, pp. 1-13.

[7] Bovee, Courtland L. \& Thill, John V, Business Communication Today, England: Pearson, 2016.

[8] Christensen, D.S \& Rees, D. "An Analysis of The Business Communication Skill Needed by Entri-level Accountants." Mountains Plains Journal of Business and Economics, 2002, pp. $1-13$.

[9] Stower, Robert H. \& G. Thomas White.. "Connecting Accounting and Communication: A Survey of Public Accounting Firms", Business Communication Quarterly, 62,2,1999, 23-40.

[10] Stower, Robert H. \& G. Thomas White.. "Connecting Accounting and Communication: A Survey of Public Accounting Firms", Business Communication Quarterly, 62,2,1999, 23-40.

[11] Riley, Tracey J. \& Kathleen A. Simons, "The Written Communication Skills That Matter Most of Accountants", Accounting Education, 25, 3, 2016, pp. 239-255.

[12] Riley, Tracey J. \& Kathleen A. Simons, "The Written Communication Skills That Matter Most of Accountants", Accounting Education, 25, 3, 2016, pp. 239-255.

[13] Siriwardane, Harsini P. \& Christ H. Durden, "The Communication Skill of Accountants: What We Know and The Gaps in Our Knowledge", Accounting Education, 2, 23, 2014,pp. 119-134.

[14] Siriwardane, Harsini P. \& Christ H. Durden, "The Communication Skill of Accountants: What We Know and The Gaps in Our Knowledge", Accounting Education, 2, 23, 2014,pp. 119-134.

[15] Riley, T.J. \& Simon, K.A, "The Written Communication Skills That Matter Most of Accountants", Accounting Education”, 25, 3, 2016, pp. $239-255$. 
[16] D. Setyaningrum, A. Muktiuanto, A.A.Hermawan, "How Indonesian Accounting Education Provides Meet The Demand of The Industry," International Research Journal of Business Studies, 8,1, pp. $1-11$.

[17] Siriwardane, Harsini P. \& Christ H. Durden, "The Communication Skill of Accountants: What We Know and The Gaps in Our Knowledge", Accounting Education, 2, 23, 2014,pp. 119-134.

[18] DÖrnyei, Z, Research Methods in Apllied Linguistics, Oxford: Oxford University Press, 2017

[19] Murphy, Herta A. \& Herbert W. Hildebrandt, Effective Business Communication. NY: McGraw Hill, 1991,

[20] Lehtonen, T. \& Karjalaineen, S, "University Graduates' Workplace Language Needs as Perceived by Employers", Systems, 36,2008. pp. 492-503.

[21] Riley, Tracey J. \& Kathleen A Simon, "The Written Communication Skills That Matter Most of Accountants", Accounting Education, 25, 3, 2016, pp. 239-255. 